\title{
Congenital fibrovascular pupillary membrane
}

\author{
Membrana pupilar fibrovascular congênita
}

Mauro Waiswol ${ }^{1}$, Fábio Ejzenbaum ${ }^{1}$, Davi Chen $\mathrm{Wu}^{1}$, Eduardo Kagohara ${ }^{1}$, José Ricardo de Abreu Reggi ${ }^{1}$

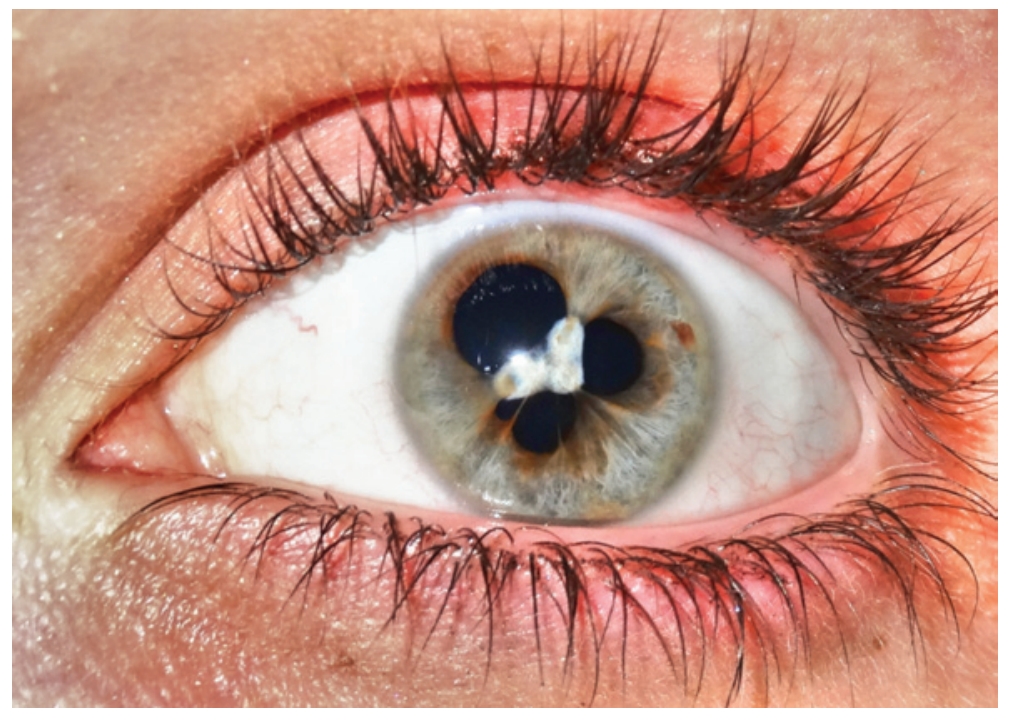

Figure 1. Congenital fibrovascular pupillary membrane

Congenital fibrovascular pupillary membrane ${ }^{(1-4)}$ is an unilateral ocular change of the anterior segment (Figure 1). This abnormality was first reported by Cibis et al. in $1986 .^{(5)}$

In some cases, progressive miosis, posterior embryotoxon and abnormality of the anterior chamber angle have been documented. Pupillary membrane might not be adhered to crystalline, or it can also be associated with anterior capsular cataract. ${ }^{(6)}$

Instillation of mydriatic agents, normally results in poor pupillary dilation, because of adherences between pupillary membrane and the iris, or posterior synechiae. ${ }^{(7)}$

When the red reflex is no longer visible or severely compromised, surgery should immediately be indicated, with the aim to rescue the view and prevent amblyopia. ${ }^{(8-10)}$
These eyes are usually treated with a membranectomy and pupilloplasty with or without a lensectomy.

After fulfilling the anterior chamber with the viscoelastic, the pupil was mechanically distended and subsequently the fibrovascular membrane was resected (sphincterectomy was not required). For patients who require only membranectomy, it is important to be careful as not to cause traumatic cataract, by accidently touching the anterior capsule of the crystalline.

In the postoperative period, the left eye was treated with prednisolone acetate $1 \%$ and cyclopentolate chloridrate $1 \%$ eyedrops. Crystalline lenses remained clear on both eyes. Posterior to that, glasses were prescribed and occlusion antisupressive therapy in partial time, of contralateral eye.

\footnotetext{
${ }^{1}$ Santa Casa de Misericórdia de São Paulo, São Paulo, SP, Brazil.
}

Corresponding author: Mauro Waiswol - Avenida Albert Einstein, 627/701, building A1, 1ํ floor, room 106B - Morumbi - Zip Code: $05652-900$ - São Paulo, SP, Brazil - Phone: (55 11) 2151-9991 E-mail:waiswol@terra.com.br

Received on: May 23, 2013 - Accepted on: Dec 27, 2013

DOI: 10.1590/S1679-45082015AI2850 
Congenital fibrovascular pupillary membrane is often characterized in its histology, ${ }^{(7)}$ for presenting fibrovascular tissue, containing venules and arterioles, fibrocytes and extracellular collagen and immunoreactive elongated cells for smooth muscle.

The congenital fibrovascular pupillary membranes, can return if not completely removed. Progressive miosis associated to the recurrence of these membranes is, probably mediated by myofibroblast.

In conclusion, when indicated, the surgery must be conducted as early as possible, otherwise, an irreversible visual dysfunction may appear due to stimulus deprivation, causing the amblyopia.

\section{REFERENCES}

1. Jacobs M, Jaouni Z, Crompton J, Kriss A, Taylor D. Persistent pupillary membranes. J Pediatr Ophthalmol Strabismus. 1991;28(4):215-8.

2. Muen WJ, Roberts $C$, Sagoo MS, Reddy MA. Persistent fetal vasculature. Ophthalmology. 2012;119(9):1944-5.e1-2.
3. Norris $\mathrm{JH}$, Backhouse $\mathrm{OC}$. The congenital pinhole: a persistent pupillary membrane. Clin Exp Optom. 2010;93(2):100-1.

4. Tartarella MB, Takahagi RU, Braga AP, Fortes Filho JB. Persistent fetal vasculature: ocular features, management of cataract and outcomes. Arq Bras Oftalmol. 2013;76(3):185-8.

5. Cibis GW, Waeltermann JM, Hurst E, Tripathi RC, Richardson W. Congenital pupillary-iris-lens membrane with goniodysgenesis (a new entity). Ophthalmology. 1986;93(6):847-52.

6. Müllner-Eidenböck A, Amon M, Moser E, Klebermass N. Persistent fetal vasculature and minimal fetal vascular remnants: a frequent cause of unilateral congenital cataracts. Ophthalmology. 2004;111(5):906-13.

7. Lambert SR, Buckley EG, Lenhart PD, Zhang 0, Grossniklaus HE. Congenital fibrovascular pupillary membranes: clinical and histopathologic findings. Ophthalmology. 2012;119(3):634-41.

8. Curi R, Herzog Neto G. Câmara AG. Ambliopia por persistência de membrane pupilar. Rev Bras Oftalmo. 1986;45(5):15-7.

9. Kesarwani S, Murthy R, Vemuganti GK. Surgical technique for removing congenital fibrovascular pupillary membrane, with clinicopathological correlation. J AAPOS. 2009;13(6):618-20

10. Thacker NM, Brit MT, Demer JL. Extensive persistent pupillary membranes: conservative management. J AAPOS. 2005;9(5):495-6. 